\title{
MANIPULATION OF FIRE ANT DENSITY, Solenopsis spp., FOR SHORT-TERM REDUCTION OF Diatraea saccharalis LARVAL DENSITIES IN BRAZIL
}

\author{
Marcelo Nogueira Rossi ${ }^{\text {** }}$; Harold Gordon Fowler² \\ ${ }^{1}$ Depto. de Zoologia - UNESP, C.P. 510 - CEP: 18618-000 - Botucatu,SP. \\ ${ }^{2}$ Depto. de Ecologia - UNESP, C.P. 199 - CEP: 13506-900 - Rio Claro,SP. \\ ${ }^{*}$ Corresponding author <rossilife@fca.unesp.br>
}

\begin{abstract}
The sugarcane borer, Diatraea saccharalis (Fabr.) is the main sugarcane pest in Brazil. In the State of São Paulo, the main active population control of $D$. saccharalis is by inundative releases of the exotic parasitoid, Cotesia flavipes (Cam.). However, the production of $C$. flavipes in sugar mills entails costs and few studies have evaluated the effects of native predators on sugarcane borer populations. Using a simple colony translocation method, we evaluated the effect of fire ants (Solenopsis spp.) on population densities of $D$. saccharalis and concurrently upon rates of parasitism by classical biological control agents in the São João sugar mill in the State of São Paulo, Brazil. The translocation technique proved to be feasible and economically possible. Sugarcane

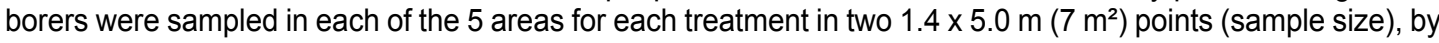
opening and visually examining all canes. The average numbers and its respective standard deviations (SD) for $D$. saccharalis population densities before and after colony translocations considering $0,5,10$ and 15 colonies added per 0.5 ha were, $9.2 \pm 5.9,8.4 \pm 3.4,9.0 \pm 6.9,9.4 \pm 8.1$ and $3.2 \pm 1.8,2.8 \pm 2.7,2.6 \pm 1.5,3.8 \pm 2.8$, respectively. However, we detected no significant changes in sugarcane borer densities with respect to ant colony densities over a two-week period, none of which were greater than for no colony additions. No effects of colony translocations on parasitism rates of braconid and tachinid parasitoids on $D$. saccharalis were detected. Thus, although the translocation technique was economically feasible, no reductions of $D$. saccharalis densities were produced by colony additions, and may not be a viable alternative for $D$. saccharalis population reduction, especially at the low population levels which prevail in Brazil.
\end{abstract}

Key words: sugarcane borer, predation, colony translocation, parasitoids

\section{MANIPULAÇÃO DA DENSIDADE DE FORMIGAS LAVA-PÉ, Solenopsis spp., PARA REDUÇÃO A CURTO PRAZO DAS DENSIDADES LARVAIS DA Diatraea saccharalis NO BRASIL}

\begin{abstract}
RESUMO: A broca da cana-de-açúcar, Diatraea saccharalis (Fabr.) é a principal praga da cana-de-açúcar no Brasil. No Estado de São Paulo, o principal meio de controle desta praga é por meio de liberações constantes do parasitóide exótico Cotesia flavipes (Cam.). De qualquer forma, a produção de tais parasitóides nas usinas de cana-de-açúcar acarreta custos e poucos estudos tem avaliado os efeitos de predadores nativos nas populações da broca da cana-de-açúcar. Usando-se um método simples de coleta e liberação de colônias, avaliou-se o efeito de formigas Solenopsis spp. nas densidades das populações de $D$. saccharalis, bem como seu efeito na taxa de parasitismo imposta por agentes de controle biológico clássico. O estudo foi conduzido nos canaviais da Usina São João, município de Araras-SP. Esta metodologia mostrou ser apropriada e economicamente viável. Lagartas de $D$. saccharalis foram amostradas em cada uma das cinco áreas de cada tratamento em dois pontos de $1.4 \times 5.0$ $\mathrm{m}\left(7 \mathrm{~m}^{2}\right)$ (tamanho amostral), através da abertura e observação de todas as plantas ali existentes. Os números médios e os respectivos desvios padrão para as densidades populacionais de $D$. saccharalis, antes e após a adição de 0,5 , 10 e 15 colônias por 0.5 ha, foram, 9,2 $\pm 5,9 ; 8,4 \pm 3,4 ; 9,0 \pm 6,9 ; 9,4 \pm 8,1$ e 3,2 $\pm 1,8 ; 2,8 \pm 2,7 ; 2,6$ $\pm 1,5 ; 3,8 \pm 2,8$; respectivamente. De qualquer forma, durante um período de duas semanas, nenhuma mudança significativa nas densidades de $D$. saccharalis foi detectada, as quais não diferiram das áreas onde não houve liberação de colônias. Nenhum efeito, devido à adição das colônias, nas taxas de parasitismo impostas pelos braconídeos e taquinídeos foi detectada. Portanto, embora esta metodologia foi economicamente viável, nenhuma redução nas densidades de $D$. saccharalis foi evidenciada devido à adição das colônias, não sendo uma alternativa viável para a redução das densidades populacionais de $D$. saccharalis.
\end{abstract}

Palavras-chave: broca da cana-de-açúcar, predação, manipulação de colônias, parasitóides

\section{INTRODUCTION}

The sugarcane borer, Diatraea saccharalis (Fabr.) (Lepidoptera: Crambidae) is the main sugarcane,
Saccharum spp., pest in Brazil (Gallo et al., 1988). It causes direct injury through gallery construction, leading to weight loss and germination failure, and indirect losses by facilitating fungus infections that lead to sucrose 
inversion and a consequent loss of sugar during refinement (Gallo et al., 1988). In the São Paulo State, Brazil, the main active population control of $D$. saccharalis is by inundative releases of the exotic parasitoid, Cotesia flavipes (Cam.) (Hymenoptera: Braconidae) and current infestation rates are approximately 2\% (Botelho, 1992; Botelho et al., 1999). However, the production of $C$. flavipes in sugar mills entails costs and few studies have evaluated the effects of native predators on sugarcane borer populations.

Generalist predators can be effective regulatory agents of pest populations because they can adjust predation between a number of prey population, whether these are primary or secondary pests (Luff, 1983). Ants are prominent among the fauna of generalist predators of the sugarcane borer (Botelho et al., 1986), and have been reported to be the primary predators of eggs (Degaspari et al., 1987). Of these, fire ants, Solenopsis spp. (Hymenoptera: Formicidae), are among the most prevalent (Fowler et al., 1991). Introduced populations of $S$. invicta (Buren) have been shown to have a strong role in the population suppression of $D$. saccharalis in the United States (Charpentier et al., 1967; Negm \& Hensley, 1969; Reagan et al., 1972), and constitute the most abundant ant species in sugarcane (Adams et al., 1981). Fire ants have been shown to be key predators for row crop pests in the Neotropics (Risch \& Carroll, 1982) and a variety of pests in Florida and Louisiana (Hu \& Frank, 1996a, b; Fuller et al., 1997).

Fire ants are native to Brazil and are also prominent faunal elements of sugarcane plantations (Fowler et al., 1991). Because fire ants frequently nest in the upper soil layer and do not construct deep nests as most of the other native ants, fire ant nests could potentially be collected and translocated to other areas. In tropical tree crops, ant manipulation, through selective elimination, translocation, habitat modification, and other techniques, has been employed for pest control (Majer, 1982). Studying the effects of ant predation on $D$. saccharalis larval populations in artificially infested sugarcane fields (State of São Paulo, Brazil), Rossi \& Fowler (2000) observed a clear trend of reduction in $D$. saccharalis larval densities in areas without ant suppression (insecticidal check techniques) and fire ants were always the most abundant ant. Could fire ant colony translocation be used to augment the natural control of pests in non-tree crop situations? Would a predator augmentation program interfere with other biological control agents?

Here we report on techniques for colony translocation and an experimental evaluation of differing colony density translocations on populations of $D$. saccharalis in sugarcane plantations in São Paulo, Brazil, as well as their interactions with native (Tachinidae) and exotic (C. flavipes) parasitoids.

\section{MATERIAL AND METHODS}

Studies were conducted for the sugarcane varieties SP79-1011 planted in the São Joao Sugar Mill, in Aguaí, São Paulo (lat. 22 $04^{\prime} 00^{\prime \prime}$ long. 4659'30"). Fire ant colonies [either S. invicta or S. saevissima (Forel)] were located by mound sightings along roadsides, collected during the morning with shovels and placed into individual plastic bags (20 liters). The plastic bags were then closed to prevent escape. To minimize fire ant stings, rubber gloves were dusted with baby powder during colony excavations. Vegetation-free mounds were chosen to speed colony excavation.

Collected colonies were placed in the back of a pick-up truck and in the afternoon were transplanted to experimental areas. Upon arrival in the experimental areas, bags were opened and dumped into 6 liter plastic buckets, and thereafter each was considered a standardized colony. Thus, extremely large colonies could be divided into two or more standardized colony transplants. Using this technique approximately 50 colonies were collected and translocated per day.

Experimental translocation colony densities were 0 (control), 5, 10, and 15 per 0.5 ha., each replicated five times. Each experimental area was comprised of 36 rows of sugarcane by $100 \mathrm{~m}$ in length ( $0.5 \mathrm{ha})$. A minimum spacing of 40 rows separated each experimental plot. For transplant densities of 15 standardized colonies, 5 were dumped between the 9th and 10th rows, 5 between the 18th and 19th rows, and 5 between the 27th and 28th rows. For areas in which 10 standardized colonies were transplanted, 5 were dumped between the 10th and the 11 th rows and 5 between the 26th and 27th rows. For areas of 5 standardized colony additions, these were dumped between the 18th and 19th rows. For all colony translocation treatments, individual standardized colonies were dumped at a $15 \mathrm{~m}$ spacing. Sugarcane borers were sampled in each of the 5 areas for each treatment in two $1.4 \times 5.0 \mathrm{~m}\left(7 \mathrm{~m}^{2}\right)$ points, by opening and visually examining all canes. Data for each sampled area were summed to represent experimental area sugarcane borer densities. Samples were conducted prior to and fifteen days after colony translocations. Caterpillars collected during sampling were taken to the laboratory and reared on artificial diet in $(65 \mathrm{~mm} \times 30 \mathrm{~mm})$ petri plates to evaluate parasitism [ $C$. flavipes and the native tachinids Lydella minense (Towns.) and Paratheresia claripalpis (Wulp.)]. Parasitoid emergences from collected caterpillars were used to calculate percentage parasitism for each experimental area, both before and after colony transplants.

Averages and standard deviations for $D$. saccharalis population densities and parasitism subjected to differing levels of fire ant colony translocations in sugarcane plantations were calculated, considering the five experimental plots used for all colony addition treatments. Because of the non-normality of the data, the 
Kruskal-Wallis test (Zar, 1984) was used to evaluate treatment effects on larval sugarcane borer densities and parasitism percentages before and after colony translocations.

\section{RESULTS AND DISCUSSION}

Means and standard deviations for $D$. saccharalis population densities and parasitism subjected to differing levels of fire ant colony translocations are shown (Table 1). No differences were found in larval sugarcane borer densities before and fifteen days after colony translocations at any colony addition level $(P=0.9423)$ (Table 2). The same was true for parasitism percentages before and after colony translocations $(P=0.1401$ and $P=0.8308$, respectively) (Table 2 ).

Our experimental manipulation of fire ant densities in sugarcane fields was used to test an economically feasible alternative for the control of $D$. saccharalis in São Paulo, Brazil. Colony collection and translocation was cheap, quick, and could be easily incorporated into the strategy of sugar mill operations, especially since unqualified labour could perform this task. Fire ant mounds were easily identified and collected.

No differences in $D$. saccharalis were found with respect to colony additions, at any level, over the 2 weeks time period examined. Parasitism also showed no effects due to either colony additions or to changes in $D$. saccharalis densities, and thus could likewise not be responsible for the observed $D$. saccharalis declines in all experimental units. However, since $D$. saccharalis population levels are now extremely low in cane plantations of São Paulo State (Botelho, 1992), our experimental design reflected reality, as well as did the time period evaluated. Shorter or longer time periods would not be economically feasible. Additionally, colony transplants, which may or may have not included queens, but did include brood, resulted in rapid nest reconstruction, and may not have lasted more than a few weeks, due to colony death or potential movement from the transplant area (Harold G. Fowler, personal communication). Even though this technique was not successful in reducing larval numbers, it may be used to reduce larval numbers if the ants were added when the eggs or early instars were present in the field (Rossi \& Fowler, 2000). The short-term (2-week) timeframe of this study may not have detected effects that would not have been noticed until several weeks later. Because of the patchiness of $D$. saccharalis in Brazilian sugarcane this does not imply that ants may have a regulatory capability at higher $D$. saccharalis densities, not evaluated here.

In spite of the lack of a clear effect of fire ant augmentation on cane borer populations, colony translocations may be useful for other cropping systems.

\section{ACKNOWLEDGMENTS}

We acknowledge the São João Sugar Mill for providing experimental areas and field assistance through Maria Aparecida Piva and Luis Carlos Lacerda Resende. Luis Carlos Forti for his helpful comments and encouragement during this study, and $\mathrm{CNPq}$ for financial support.

Table 1 - Averages and standard deviations (SD) for Diatraea saccharalis population densities and the percentage of parasitism subjected to differing levels of fire ant colony translocations in sugarcane plantations in São Paulo, Brazil. Five experimental plots were used for all colony addition treatments, and sugarcane borers were sampled in each of these 5 areas for each treatment in two $1.4 \times 5.0 \mathrm{~m}\left(7 \mathrm{~m}^{2}\right)$ points (sample size).

\begin{tabular}{ccccc}
\hline $\begin{array}{c}\text { Colonies } \\
\text { added }\end{array}$ & $\begin{array}{c}\text { Mean } \pm \text { SD number of } D . \\
\text { saccharalis larvae } \\
\text { sampled before colony } \\
\text { addition }\end{array}$ & $\begin{array}{c}\text { Mean } \pm \text { SD number of } \\
\text { D. saccharalis larvae } \\
\text { sampled after colony } \\
\text { addition }\end{array}$ & $\begin{array}{c}\text { Mean } \pm \text { SD percentage } \\
\text { of } D \text {. saccharalis larvae } \\
\text { parasitized before colony } \\
\text { addition }\end{array}$ & $\begin{array}{c}\text { Mean } \pm \text { SD percentage } \\
\text { of } D \text {. saccharalis } \\
\text { larvae parasitized after } \\
\text { colony addition }\end{array}$ \\
\hline 0 & $9.2 \pm 5.9$ & $3.2 \pm 1.8$ & $9.0 \pm 5.3$ & $12.0 \pm 17.9$ \\
5 & $8.4 \pm 3.4$ & $2.8 \pm 2.7$ & $19.9 \pm 6.0$ & $16.7 \pm 15.6$ \\
10 & $9.0 \pm 6.9$ & $2.6 \pm 1.5$ & $13.3 \pm 10.3$ & $10.7 \pm 15.3$ \\
15 & $9.4 \pm 8.1$ & $3.8 \pm 2.8$ & $11.6 \pm 13.8$ & $29.0 \pm 41.3$ \\
\hline
\end{tabular}

Table 2 - Ranked population parameters for Diatraea saccharalis population changes and parasitism subjected to differing levels of fire ant colony translocations in sugarcane plantations in Sao Paulo, Brazil. Five experimental plots were used for all colony addition treatments. For all measured parameters, no differences were found with respect to the number of colonies added.

\begin{tabular}{cccc}
\hline Colonies added & $\begin{array}{c}\text { Mean rank difference of } D . \\
\text { saccharalis before and after } \\
\text { colony addition }\end{array}$ & $\begin{array}{c}\text { Mean rank of \% parasitism } \\
\text { before colony addition }\end{array}$ & $\begin{array}{c}\text { Mean rank of \% parasitism } \\
\text { after colony addition }\end{array}$ \\
\hline 0 & 10.4 & 6.9 & 9.5 \\
5 & 11.1 & 15.3 & 11.7 \\
10 & 11.3 & 10.6 & 9.2 \\
15 & 9.2 & 9.2 & 11.6 \\
\hline
\end{tabular}




\section{REFERENCES}

ADAMS, C.T.; SUMMERS, T.E.; LOFGREN, C.S.; FOCKS, D.A.; PREWITT, J.C. Interrelationship of ants and the sugarcane borer in Florida sugarcane fields. Environmental Entomology, v.10, p.415-418, 1981.

BOTELHO, P.S.M. Quinze anos de controle biológico da Diatraea saccharalis utilizando parasitóides. Pesquisa Agropecuária Brasileira, v.27, p.255262, 1992

BOTELHO, P.S.M.; PARRA, J.R.P.; NETO, J.F.C.; OLIVEIRA, C.P.B Associação do parasitóide de ovos Trichogramma galloi Zucchi (Hymenoptera:Trichogrammatidae) e do parasitóide larval Cotesia flavipes (Cam.) (Hymenoptera: Braconidae) no controle de Diatraea saccharalis, (Fabr.) (Lepidoptera: Crambidae) em cana-de-açúcar. Anais da Sociedade Entomológica do Brasil, v.28, p.491-496, 1999.

BOTELHO, P.S.M.; MACEDO, N.; ALMEIDA, L.C.; CASTILHO, H.J.; ARAUJO J.R. Inovações tecnológicas visando o controle integrado de Diatraea saccharalis. In: BOTELHO, P.S.M. (Ed.) Avaliação do controle biológico da broca da cana-de-açúcar, Diatraea saccharalis. Sertãozinho: Coopersucar, 1986. p.50-79.

CHARPENTIER, L.J.; MCCORMICH, W.J.; MATHES, R. Beneficial arthropods inhabiting sugarcane fields and their effect on borer infestation. Sugar Bulletin, v.45, p.276-277, 1967.

DEGASPARI, N.; MACEDO, N.; BOTELHO, P.S.M.; ARAUJO, J.R.; ALMEIDA L.C. Predadores e parasitos de ovos de Diatraea saccharalis em canade-açúcar. Pesquisa Agropecuária Brasileira, v.22, p.785-792, 1987

FOWLER, H.G.; FORTI, L.C.; BRANDÃO, C.R.F.; DELABIE, J.H.C. VASCONCELOS, H.L. Ecologia nutricional de formigas. In: PANIZZI, A. PARRA, J.R.P. (Ed.) Ecologia nutricional de insetos e suas implicações no manejo de pragas. São Paulo: Manole, 1991. p.131-223.

FULLER, B.W.; REAGAN, T.E.; FLYNN, J.L.; BOETEL, M.A. Predation on fall armyworm (Lepidoptera: Noctuidae) in sweet sorghum. Journal of Agricultural Entomology, v.14, p.151-155, 1997.
GALLO, D.; NAKANO, O.; SILVEIRA-NETO, S.; CARVALHO, R.P.L.; BATISTA, G.C.; BERTI-FILHO, E.; PARRA, J.R.P.; ZUCCHI, R.A.; ALVES, S.B.; VENDRAMIM, J.D. Manual de entomologia agrícola. São Paulo: Editora Agronômica Ceres, 1988. 649p.

HU, G.Y.; FRANK, J.H. Effect of the arthropod community on survivorship of immature Haematobia irritans (Diptera: Muscidae) in north central Florida. Florida Entomologist, v.79, p.497-503, 1996a.

HU, G.Y.; FRANK, J.H. Effect of the red imported fire ant (Hymenoptera: Formicidae) on dung-inhabiting arthropods in Florida. Environmental Entomology, v.25, p.1290-1296, 1996b.

LUFF, M.L. The potential of predators for pest control. Agriculture, Ecosystems and Environment, v.10, p.159-181, 1983.

MAJER, J.D. Ant manipulation in agro and forest ecosystems. In: BREED M.D.; MICHENER, C.D.; EVANS, H.E. (Ed.) Biology of social insects. Boulder: Westview Press, 1982. p.90-97.

NEGM, A.A.; HENSLEY, S.D. Evaluation of certain biological control agents of the sugarcane borer in Louisiana. Journal of Economic Entomology, v.62, p.1008-1013, 1969

REAGAN, T.E.; COBURN, G.; HENSLEY, S.D. Effects of mirex on the arthropod fauna of a Louisiana sugarcane field. Environmental Entomology, v.1, p.588-591, 1972.

RISCH, S.J.; CARROLL, C.R. Effect of a keystone predaceous ant, Solenopsis geminata, on arthropods in a tropical agroecosystem. Ecology, v.63, p.1979-1983, 1982.

ROSSI, M.N.; FOWLER, H.G. Ant predation of larval Diatraea saccharalis Fab. (Lep., Crambidae) in new sugarcane in Brazil. Journal of Applied Entomology, v.124, p.245-247, 2000.

ZAR, J.H. Biostatistical analysis. New Jersey: Prentice-Hall, 1984. 718p.

Received September 11, 2000 